\title{
Transport of Diazinon in the San Joaquin River Basin, California
}

By Charles R. Kratzer

U.S. GEOLOGICAL SURVEY

Open-File Report 97-411

National Water Quality Assessment Program

$\infty$
$\vdots$
$\dot{1}$
$\dot{1}$

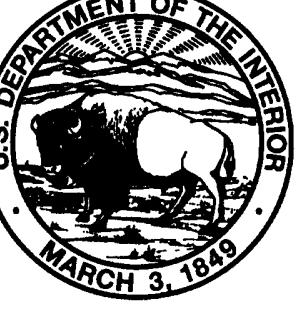




\section{U.S. DEPARTMENT OF THE INTERIOR}

BRUCE BABBITT, Secretary

U.S. GEOLOGICAL SURVEY

Gordon P. Eaton, Director

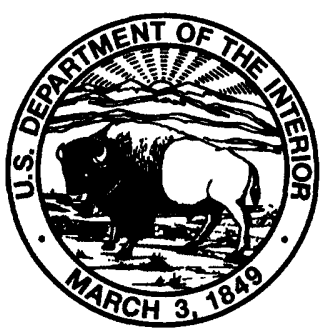

The use of firm, trade, and brand names in this report is for identification purposes only and does not constitute endorsement by the U.S. Geological Survey

For additional information write to:

District Chief

U.S. Geological Survey

Water Resources Division

Placer Hall

$6000 \mathrm{~J}$ Street

Sacramento, CA 95819-6129
Copies of this report can be purchased from:

U.S. Geological Survey

Information Services

Box 25286

Federal Center

Denver, CO 80225 


\section{FOREWORD}

The mission of the U.S. Geological Survey (USGS) is to assess the quantity and quality of the earth resources of the Nation and to provide information that will assist resource managers and policymakers at Federal, State, and local levels in making sound decisions. Assessment of water-quality conditions and trends is an important part of this overall mission.

One of the greatest challenges faced by waterresources scientists is acquiring reliable information that will guide the use and protection of the Nation's water resources. That challenge is being addressed by Federal, State, interstate, and local water-resource agencies and by many academic institutions. These organizations are collecting water-quality data for a host of purposes that include: compliance with permits and water-supply standards; development of remediation plans for specific contamination problems; operational decisions on industrial, wastewater, or watersupply facilities; and research on factors that affect water quality. An additional need for water-quality information is to provide a basis on which regionaland national-level policy decisions can be based. Wise decisions must be based on sound information. As a society we need to know whether certain types of water-quality problems are isolated or ubiquitous, whether there are significant differences in conditions among regions, whether the conditions are changing over time, and why these conditions change from place to place and over time. The information can be used to help determine the efficacy of existing waterquality policies and to help analysts determine the need for and likely consequences of new policies.

To address these needs, the U.S. Congress appropriated funds in 1986 for the USGS to begin a pilot program in seven project areas to develop and refine the National Water-Quality Assessment (NAWQA) Program. In 1991, the USGS began full implementation of the program. The NAWQA Program builds upon an existing base of water-quality studies of the USGS, as well as those of other Federal, State, and local agencies. The objectives of the NAWQA Program are to:

- Describe current water-quality conditions for a large part of the Nation's freshwater streams, rivers, and aquifers.
- Describe how water quality is changing over time.

- Improve understanding of the primary natural and human factors that affect water-quality conditions.

This information will help support the development and evaluation of management, regulatory, and monitoring decisions by other Federal, State, and local agencies to protect, use, and enhance water resources.

The goals of the NAWQA Program are being achieved through ongoing and proposed investigations of 60 of the Nation's most important river basins and aquifer systems, which are referred to as study units. These study units are distributed throughout the Nation and cover a diversity of hydrogeologic settings. More than two-thirds of the Nation's freshwater use occurs within the 60 study units and more than twothirds of the people served by public water-supply systems live within their boundaries.

National synthesis of data analysis, based on aggregation of comparable information obtained from the study units, is a major component of the program. This effort focuses on selected water-quality topics using nationally consistent information. Comparative studies will explain differences and similarities in observed water-quality conditions among study areas and will identify changes and trends and their causes. The first topics addressed by the national synthesis are pesticides, nutrients, volatile organic compounds, and aquatic biology. Discussions on these and other waterquality topics will be published in periodic summaries of the quality of the Nation's ground and surface water as the information becomes available.

This report is an element of the comprehensive body of information developed as part of the NAWQA Program. The program depends heavily on the advice, cooperation, and information from many Federal, State, interstate, Tribal, and local agencies and the public. The assistance and suggestions of all are greatly appreciated.

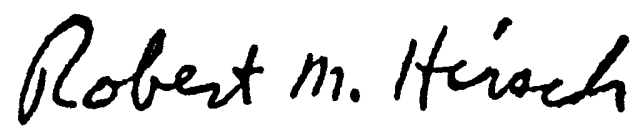

Robert M. Hirsch Chief Hydrologist 


\section{CONTENTS}

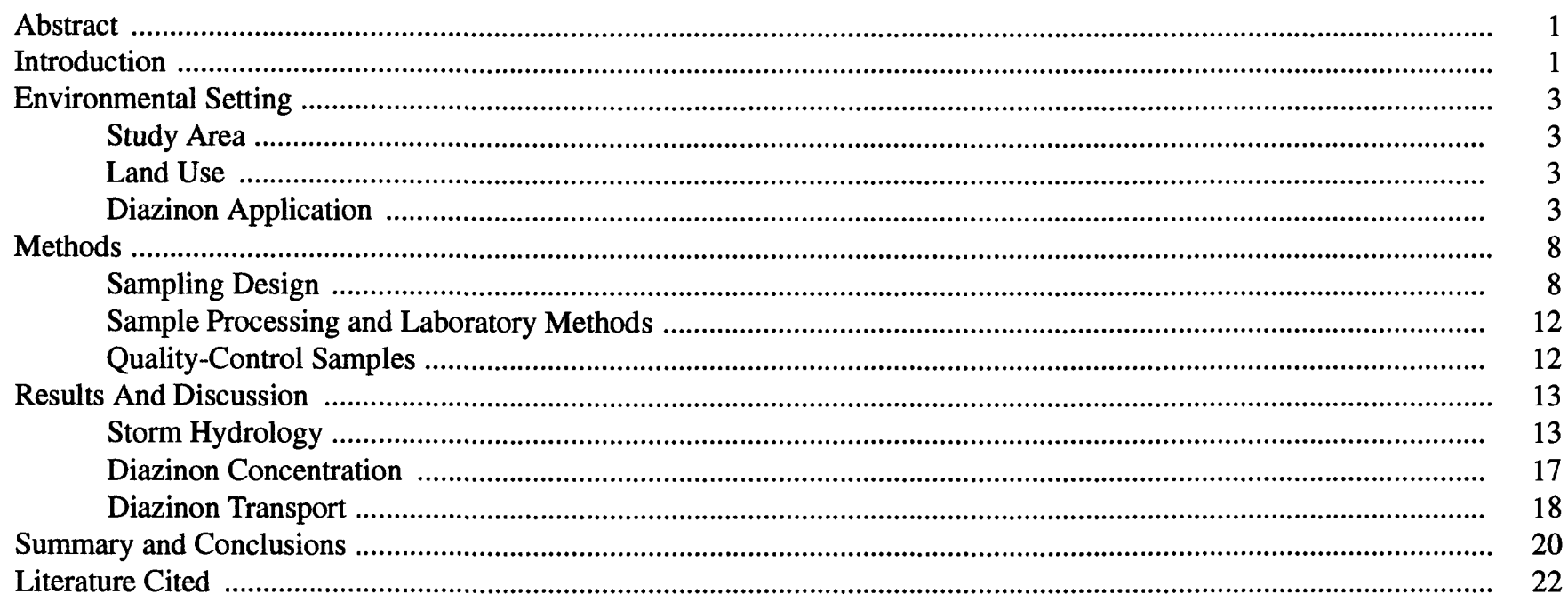

\section{FIGURES}

1-2. Maps showing:

1. Location of $(A)$ Data Sites; and $(B)$ Drainage Basins in the San Joaquin River Basin, California ....................

2. Location of $(A)$ Major Drainage Basins; $(B)$ Almond Orchards; and Diazinon Application during

(C) Dry Period 1 (December 15, 1993 to January 22, 1994), and (D) Dry Period 2 (January 26, 1994

to February 5, 1994) in the San Joaquin Valley part of the San Joaquin River Basin, California ......................

3-6. Graphs showing:

3. Monthly Diazinon Applied on Almond Orchards and on All Crops in the San Joaquin River Basin, California during Water Year 1994

4. Daily Rainfall at Modesto and Daily Diazinon Application in the San Joaquin River Basin for December 1993 through March 1994 .....

5. Rainfall, Streamflow, and Sample Collection Times for the January 1994 Storm

6. Rainfall, Streamflow, Dye Release and Recovery, and Sample Collection Times for the February 1994 Storm.

7. Map showing Precipitation Totals for the $(A)$ January 22-26, 1994, and (B) February 5-9, 1994 Storms in the

San Joaquin River Basin, California.

8-11. Graphs showing:

8. Rainfall and Storm Hydrographs in the Merced $(A, B)$, Tuolumne $(C, D)$, and Stanislaus $(E, F)$ River Basins for January and February 1994

9. Rainfall and Diazinon Concentrations and Streamflow in East-Side Basins and San Joaquin River during January and February 1994 storms 1 3 3 3 3 8 8 12

0. Diazinon Loads in the San Joaquin River near Vernalis during $(A)$ January and

(B) February 1994 Storms...

11. (A) Daily Mean Diazinon Concentrations and Streamflow; and $(B)$ Daily Diazinon Loads in the

San Joaquin River near Vernalis during February 1991 through April 1994. 


\section{TABLES}

1. Names, Locations, and Types of Data Available for Sites Shown in Figure 1

2. Basin Areas, Almond Orchard Areas, and Diazinon Application Amounts for Drainage Basins

Shown in Figure 1

\section{CONVERSION FACTORS, VERTICAL DATUM, WATER YEAR, AND ABBREVIATIONS AND ACRONYMS}

\begin{tabular}{rrl}
\hline Multiply & By & To obtain \\
\hline acre-foot $($ acre-ft) & 1,233 & cubic meter $\left(\mathrm{m}^{3}\right)$ \\
cubic foot per second $\left(\mathrm{ft}^{3} / \mathrm{s}\right)$ & 0.02832 & cubic meter per second $\left(\mathrm{m}^{3} / \mathrm{s}\right)$ \\
inch (in.) & 2.54 & centimeter $(\mathrm{cm})$ \\
mile $(\mathrm{mi})$ & 1.609 & kilometer $(\mathrm{km})$ \\
square mile $\left(\mathrm{mi}^{2}\right)$ & 2.590 & square kilometer $\left(\mathrm{km}^{2}\right)$ \\
\hline
\end{tabular}

Temperature is given in degrees Celsius $\left({ }^{\circ} \mathrm{C}\right)$, which can be converted to degrees Fahrenheit $\left({ }^{\circ} \mathrm{F}\right)$ by the following equation: ${ }^{\circ} \mathrm{F}=1.8\left({ }^{\circ} \mathrm{C}\right)+32$

\section{Vertical Datum}

Sea level: In this report, "sea level" refers to the National Geodetic Vertical Datum of 1929-a geodetic datum derived from a general adjustment of the first-order level nets of both the United States and Canada, formerly called Sea Level Datum of 1929.

\section{Water Year}

"Water year" refers to the 12-month period that starts October 1 and ends September 30 ; it is designated by the calendar year in which it ends and which contains 9 of the 12 months.

\section{Abbreviations and Acronyms}

BIOS, Biologically Integrated Orchard Systems

GC/MS, gas chromatograph/mass spectrometer

$\mathrm{lb}$ a.i., pound(s) active ingredient

MDL, method detection limit

$\mathrm{mg} / \mathrm{L}$, milligram per liter

NAWQA, National Water Quality Assessment

NWQL, National Water Quality Laboratory

$\mathrm{QC}$, quality control

SPE, solid-phase extraction

Toxics Program, Toxic Substances Hydrology Program

USGS, U.S. Geological Survey

$\mu \mathrm{g} / \mathrm{L}$, microgram per liter 


\title{
TRANSPORT OF DIAZINON IN THE SAN JOAQUIN RIVER BASIN, CALIFORNIA
}

\author{
By Charles R. Kratzer
}

\section{Abstract}

Most of the application of the organophosphate insecticide diazinon in the San Joaquin River Basin occurs in winter to control wood boring insects in dormant almond orchards. A federal-state collaborative study found that diazinon accounted for most of the observed toxicity of San Joaquin River water to water fleas in February 1993. Previous studies focused mainly on west-side inputs to the San Joaquin River. In this 1994 study, the three major east-side tributaries to the San Joaquin River, the Merced, Tuolumne, and Stanislaus Rivers, and a downstream site on the San Joaquin River were sampled throughout the hydrographs of a late January and an early February storm. In both storms, the Tuolumne River had the highest concentrations of diazinon and transported the largest load of the three tributaries. The Stanislaus River was a small source in both storms. On the basis of previous storm sampling and estimated traveltimes, ephemeral west-side creeks probably were the main diazinon source early in the storms, whereas the Tuolumne and Merced Rivers and east-side drainages directly to the San Joaquin River were the main sources later. Although 74 percent of diazinon transport in the San Joaquin River during 1991-1993 occurred in January and February, transport during each of the two 1994 storms was only 0.05 percent of the amount applied during preceding dry periods. Nevertheless, some of the diazinon concentrations in the San Joaquin River during the January storm exceeded 0.35 micrograms per liter, a concentration shown to be acutely toxic to water fleas. Diazinon concentrations were highly variable during the storms and frequent sampling was required to adequately describe the concentration curves and to estimate loads.

\section{INTRODUCTION}

The organophosphate insecticide diazinon is used widely in agricultural and urban areas. It is applied to several crops in the agriculturally dominated San Joaquin River Basin. Its most intense application takes place during January and February when it is used on dormant stone-fruit orchards to control wood boring insects. Most of this diazinon use is on almond orchards.

Diazinon persists for 10 to 12 weeks in most soils when applied at recommended rates (Howard, 1991). In water, it has a solubility of $68.8 \mathrm{mg} / \mathrm{L}$ (at $20^{\circ} \mathrm{C}$ ) and may sorb to sediments moderately, but it should not significantly bioconcentrate in aquatic organisms (Howard, 1991). Hydrolysis, biodegradation, and volatilization may be significant fate processes for diazinon in natural waters. Hydrolysis

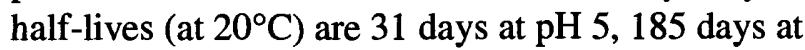
$\mathrm{pH} 7.4$, and 136 days at $\mathrm{pH} 9$ (Howard, 1991).

Previous studies have identified toxic levels of diazinon to Ceriodaphnia dubia (water flea) in the San Joaquin River (Kuivila and Foe, 1995). Results of 7-day bioassays indicated that the San Joaquin River near Vernalis (Figure $1 A$, site no. 25) was acutely toxic to Ceriodaphnia dubia for 12 consecutive days in February 1993, with daily diazinon concentrations ranging from 0.148 to $1.07 \mu \mathrm{g} / \mathrm{L}$ (Kuivila and Foe, 


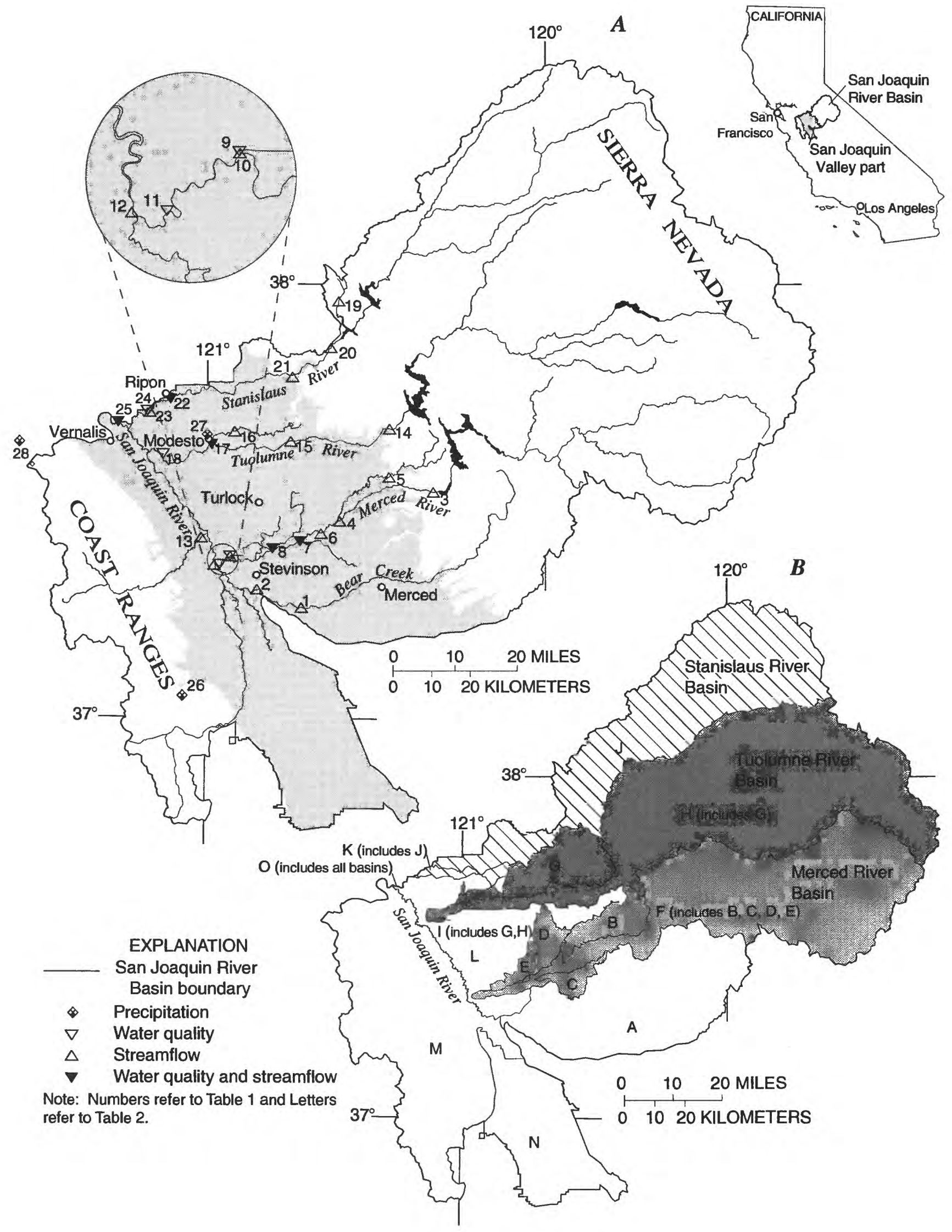

Figure 1. Location of ( $A$ ) Data Sites; and $(B)$ Drainage Basins in the San Joaquin River Basin, California. 
1995). In a study of toxicity in wastewater treatment plant effluent, Amato et al. (1992) determined an $\mathrm{LC}_{50}$ (concentration lethal to 50 percent of a test population) of $0.35 \mu \mathrm{g} / \mathrm{L}$ for the toxicity of diazinon to Ceriodaphnia dubia. Domagalski et al. (1997) determined that diazinon inputs to the San Joaquin River from several west-side sources probably accounted for an early peak in diazinon concentrations near Vernalis during a February 1993 storm; and east-side sources (especially the Merced River) probably accounted for a later peak in diazinon concentrations near Vernalis. Also, limited storm sampling of east-side inputs by state agencies identified the Merced River as a significant source of diazinon to the San Joaquin River (Ross, et al., 1996; Christopher Foe, California Regional Water Quality Control Board, written communication, 1993).

The purpose of this paper is to describe the variability in diazinon concentrations in, and determine the significance of, east-side sources to total diazinon transport in the San Joaquin River Basin. The study was part of the National Water Quality Assessment (NAWQA) Program of the U.S. Geological Survey (USGS). Two storms were sampled during the winter of 1994 following most of the application of diazinon on dormant orchards. The storms occurred during January 23-25, 1994, and February 6-8, 1994, and resulted in 1.31 and 0.77 in., respectively, of rain at Modesto (Figure 1). These storms were preceded by two dry periods that were suitable for dormant spray application: December 15, 1993 to January 22, 1994 (dry period 1), and January 26, 1994 to February 5, 1994 (dry period 2).

\section{ENVIRONMENTAL SETTING}

\section{Study Area}

The perennial San Joaquin River Basin drains $7,345 \mathrm{mi}^{2}$, of which $4,299 \mathrm{mi}^{2}$ are in the Sierra Nevada, $2,244 \mathrm{mi}^{2}$ are in the San Joaquin Valley, and $802 \mathrm{mi}^{2}$ are in the Coast Ranges (Figure 1A). On the basis of USGS streamflow data for 1951-1990, 67 percent of the average streamflow in the San Joaquin River comes from three of the basins that drain from the east: the Merced (15 percent), the Tuolumne (30 percent), and the Stanislaus (22 percent) Basins. The remaining streamflow comes from the Bear Creek Basin; Mud and Salt Sloughs, and ephemeral creeks that drain from the west; and drainage canals that flow directly to the San Joaquin River. The water quality, streamflow, and precipitation sites mentioned in this paper are identified in Figure 1 and Table 1.

\section{Land Use}

The targeted land use for this study was dormant orchards that received applications of diazinon. Almond orchards account for most of the orchard land use in the San Joaquin River Basin. More than 97 percent of these orchards are in the San Joaquin Valley, and less than 3 percent are in the Coast Ranges and Sierra Nevada, which are principally rangeland and forest. The greatest concentrations of almond orchards are in the east-side basins (Figure 2, Table 2), especially the area that drains directly to the San Joaquin River (basin L; $77.9 \mathrm{mi}^{2}$ of almond orchards), the Merced River Basin (basin F; $75.4 \mathrm{mi}^{2}$ of almond orchards), and the Bear Creek Basin (basin A; $41.7 \mathrm{mi}^{2}$ of almond orchards). Other major east-side basins, the Tuolumne River Basin (basin I; $20.1 \mathrm{mi}^{2}$ of almond orchards) and the Stanislaus River Basin (basin K; $16.7 \mathrm{mi}^{2}$ of almond orchards), have significantly fewer almond orchards. The west-side basins $\mathrm{M}$ and $\mathrm{N}$ account for a total of only $17.8 \mathrm{mi}^{2}$ of almond orchards.

\section{Diazinon Application}

Diazinon is applied during December through February to dormant orchards of several stone-fruits and nuts in the San Joaquin River Basin, including (in order of amount applied) almonds, apricots, peaches, prunes, and cherries. The California Department of Pesticide Regulation maintains records of application amounts of various pesticides on specific crops. The total amount of diazinon applied in the San Joaquin River Basin during water year 1994 (October 1, 1993 through September 30,1994) was 111,793 pounds active ingredient (lb a.i.) (California Department of Pesticide Regulation, 1994, 1995). The total application during the dormant period (December through February) was $63,490 \mathrm{lb}$ a.i., of which 76 percent was on almonds. The monthly amount of diazinon applied to almonds and all crops during water year 1994 is shown in Figure 3. Almond orchards accounted for only 31 percent of diazinon application outside of the dormant period. Application during this period was primarily to (in order of amount applied) almonds, 
Table 1. Names, Locations, and Types of Data Available for Sites Shown in Figure 1.

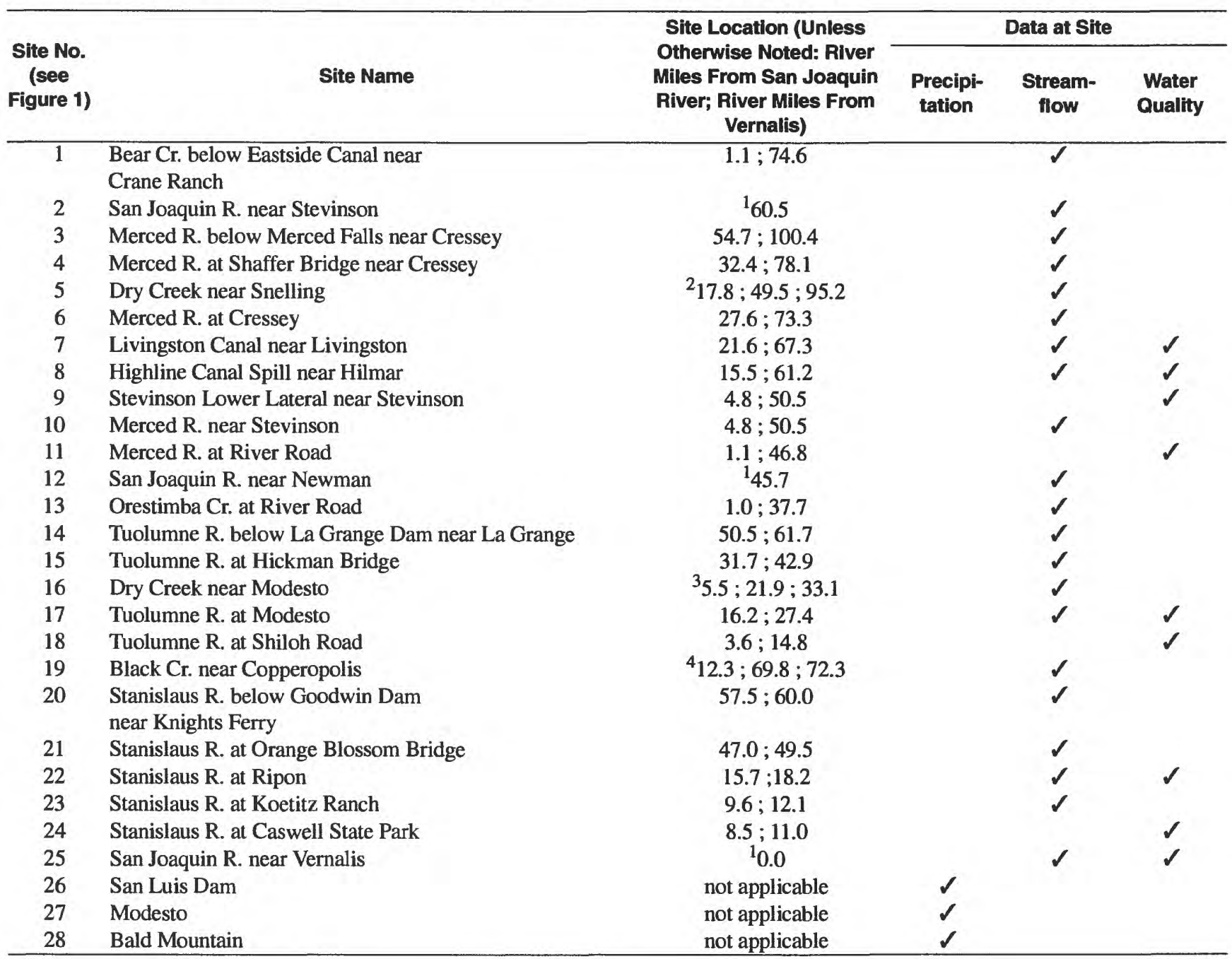

${ }^{1}$ River miles from Vernalis

${ }^{2}$ River miles from Merced R.; River miles from San Joaquin R.; River miles from Vernalis

${ }^{3}$ River miles from Tuolumne R.; River miles from San Joaquin R.; River miles from Vernalis

${ }^{4}$ River miles from Stanislaus R.; River miles from San Joaquin R.; River miles from Vernalis

apricots, melons, walnuts, alfalfa, peaches, cotton, and prunes (California Department of Pesticide Regulation, 1994, 1995).

Diazinon application amounts on all crops and on almond orchards for each drainage basin for the dry periods preceding the two storms sampled in this study are given in Table 2. Total diazinon application in the San Joaquin River Basin during dry period 1 was $38,814 \mathrm{lb}$ a.i. (78 percent on almond orchards). Application was greatest in the east-side area that drains directly to the San Joaquin River (Figure 2, basin L), west-side basins downstream of Mud and Salt Sloughs (basin M), and the Tuolumne River Basin (Table 2, basin I). Total diazinon application during dry period 2 was $17,323 \mathrm{lb}$ a.i. (79 percent on almond orchards). The application during this period was more evenly distributed, again with the greatest amount in the east-side area, which drains directly to the San Joaquin River (basin L). The unsampled subbasins of the San Joaquin River Basin (basins A, L, M, and N) received 78 and 61 percent of the total diazinon application amounts during the first and second dry periods, respectively. The diazinon application data are plotted on a statistical basis at the geographic level of a section $\left(1 \mathrm{mi}^{2}\right)$ in Figure 2. The data are presented as three application categories representing low (less than $40 \mathrm{lb}$ a.i.), medium (40-100 lb a.i.), and high (greater than $100 \mathrm{lb}$ a.i.) application areas. 


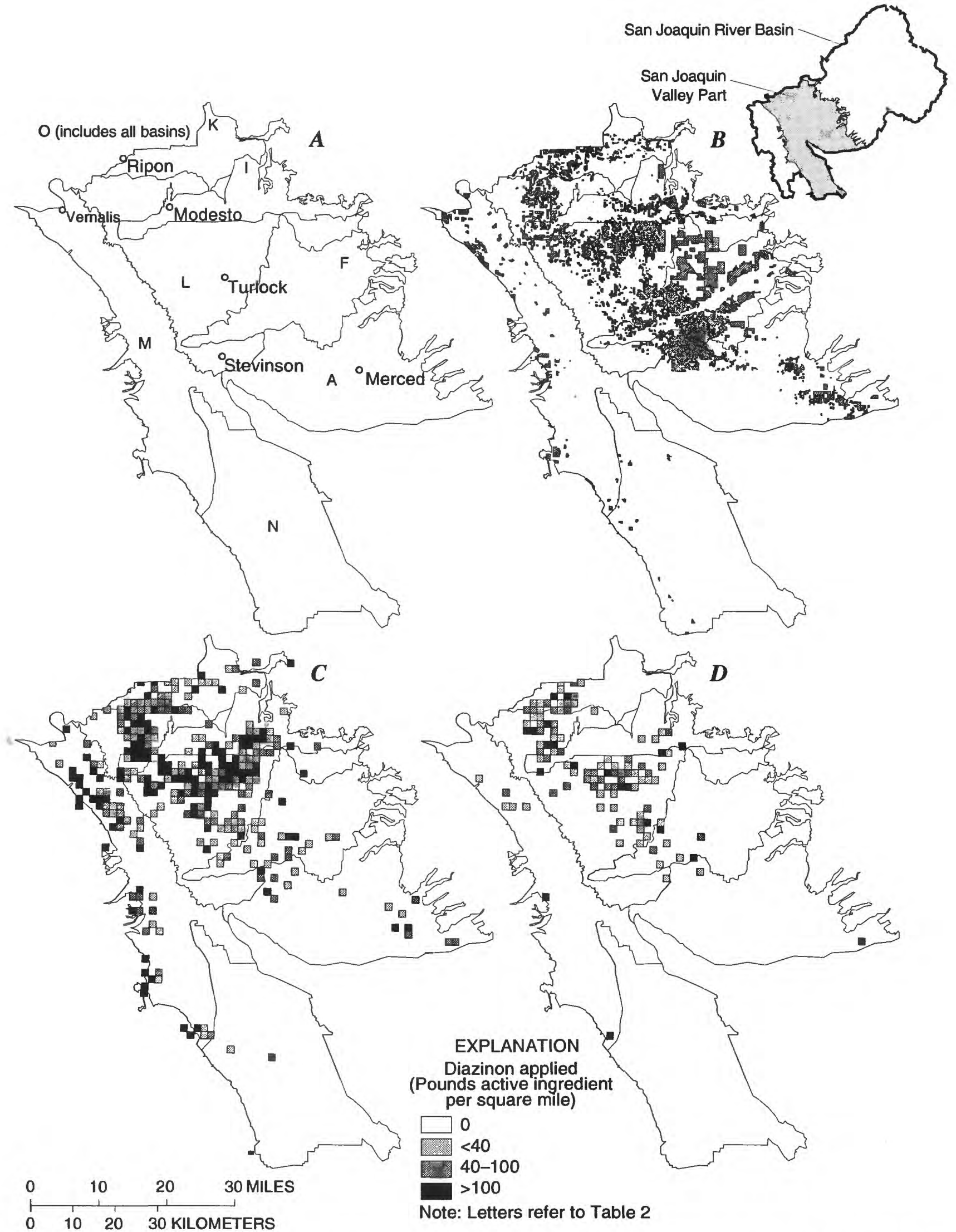

Figure 2. Location of $(A)$ Major Drainage Basins; $(B)$ Almond Orchards; and Diazinon Application during $(C)$ Dry Period 1 (December 15, 1993, to January 22, 1994), and (D) Dry Period 2 (January 26, 1994, to February 5, 1994) in the San Joaquin Valley part of the San Joaquin River Basin, California 


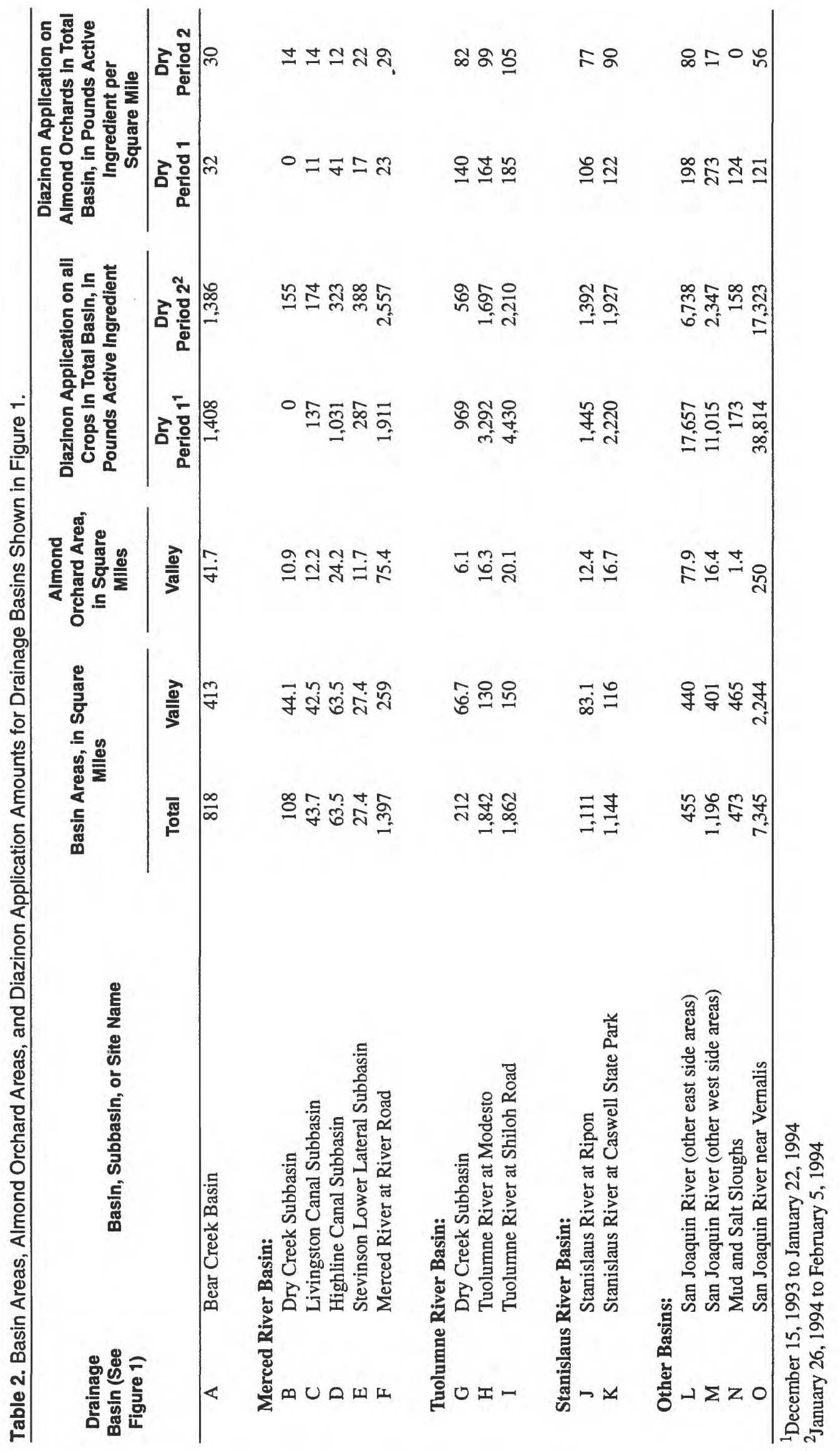




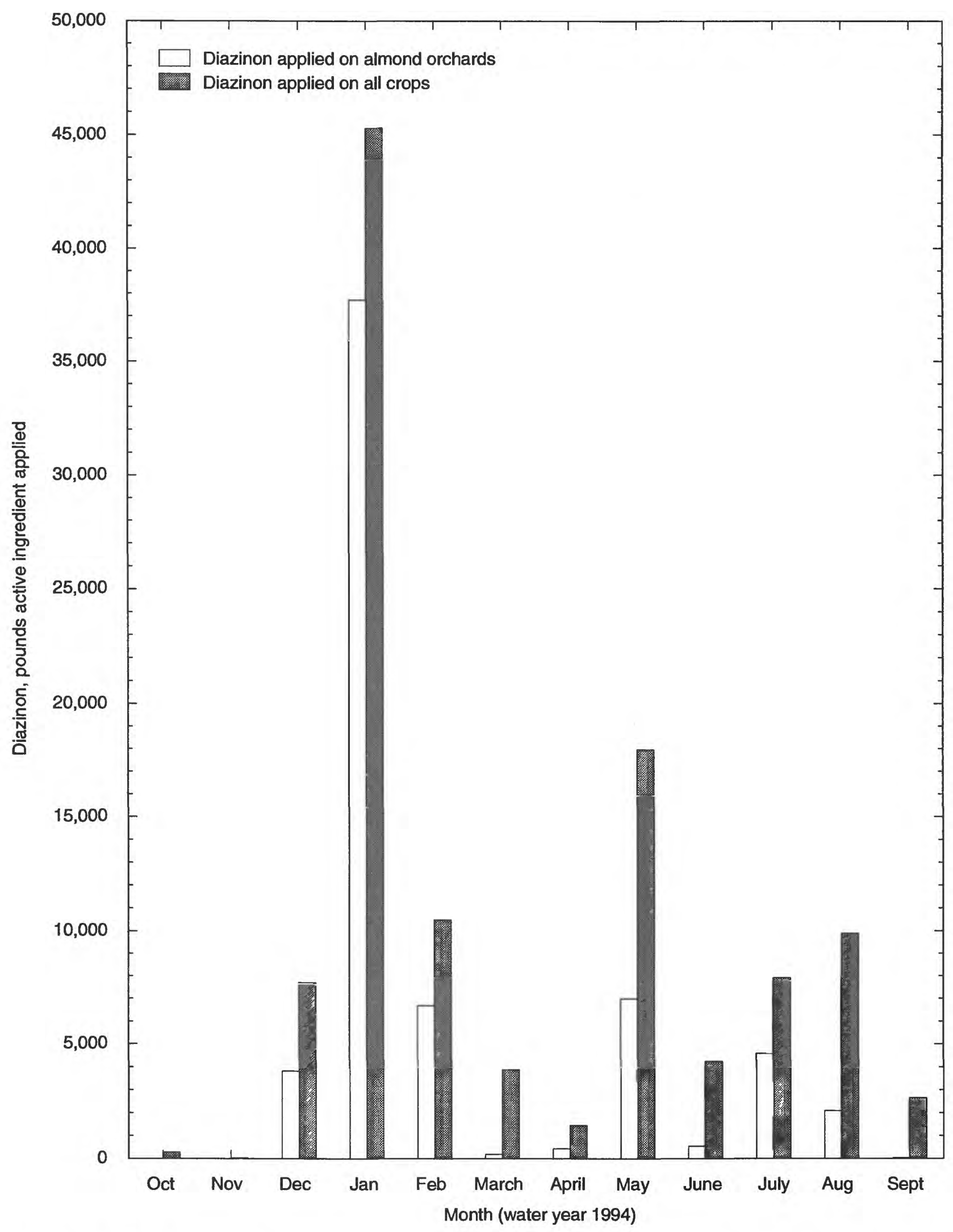

Figure 3. Monthly Diazinon Applied on Almond Orchards and on All Crops in the San Joaquin River Basin, California during Water Year 1994 (from: California Department of Pesticide Regulation, 1994 and 1995) 
Diazinon application intensity on almond orchards (in pounds active ingredient per square mile) was much lower in the Merced River (Figure 2, basin F) and Bear Creek (basin A) Basins relative to the other basins for both dry periods (Table 2). Application intensity during the second dry period was also low in the west-side basins (basins $\mathrm{M}$ and $\mathrm{N}$ ). Basins A, F, and N are primarily in Merced County, whereas the other basins are primarily in Stanislaus County. Some of the almond growers in Merced County participate in an alternative pest management program called the Biologically Integrated Orchard Systems (BIOS) program. This program is coordinated by the Community Alliance with Family Farmers and offers an array of pest management options, such as growing cover crops to harbor and attract beneficial insects; releasing predatory insects, such as trichogramma wasps, to fight pests; using oil sprays to combat mite eggs and peach twig borer on dormant orchards; and using a bacteria, Bacillus thuringiensis, at bloom time to control peach twig borer (Foe and Kuivila, 1995). The lower intensity of diazinon use in the Merced County Basins may be partly attributable to the BIOS program and also possibly to a shift to chlorpyrifos and methidathion-other organophosphate insecticides commonly used on dormant orchards.

\section{METHODS}

\section{Sampling Design}

The diazinon application on dormant orchards takes place during the peak rainfall and runoff season in the San Joaquin Valley. The city of Modesto reported a total of $10.00 \mathrm{in}$. of rainfall during water year 1994, of which 5.33 in. fell during December 1993 through March 1994 (Figure 4). The primary diazinon application was during dry periods in January and early February (Figure 4). The sampling strategy was to collect several samples at each east-side tributary and at the downstream San Joaquin River site throughout the storm hydrograph. Because previous sampling indicated that the Merced River was a significant source of diazinon, the strategy also included the collection of two samples each from two agricultural drains and a drain that consisted of agricultural and urban runoff in the Merced River Basin during the rising limb of the Merced hydrograph. Because the
Tuolumne and Stanislaus sites are several river miles from the San Joaquin River (Table 1), the strategy was to collect one sample from each river at a site closer to the San Joaquin River (Figure 1). The collection of these samples was timed to correspond with a sample at the upstream site on the rising limb of the hydrograph to look for potential downstream inputs. In addition to the NAWQA sampling, the Toxic Substances Hydrology (Toxics) Program of the USGS collected samples at the San Joaquin River site from January 1991 through April 1994. The Toxics Program sampled daily throughout the year, with more frequent sampling during winter storms (MacCoy et al., 1995). During most of the year, the Toxics Program group combined daily samples into 2-day composites for analysis; during critical periods, such as high application and runoff, daily samples were analyzed.

The January storm produced relatively small amounts of runoff in the east-side tributaries, and so, a limited version of the sampling strategy was used (Figure 5). The individual drains to the Merced River were not sampled and neither were the downstream sites on the Tuolumne and Stanislaus Rivers. Only three samples each were collected from the east-side tributaries. At the San Joaquin River site, NAWQA collected four samples during January 25-27, and the Toxics Program collected eight samples during January 22-29. The Orestimba Creek storm hydrograph is shown in Figure 5 as an example of storm runoff from ephemeral west-side creeks. The hourly rainfall shown for Orestimba Creek is the average of sites 26 and 28; Modesto rainfall (site 27) is shown for the east-side tributaries.

Because the February storm produced considerably more runoff in the east-side tributaries, the entire sampling strategy was used (Figure 6). The runoff from the west-side (see Orestimba Creek) preceded east-side runoff by about 36 hours. Overall, NAWQA collected and analyzed 53 environmental samples during the February storm runoff, and the Toxics Program collected and analyzed 12 environmental samples at the San Joaquin River site during February 6-12. In addition, NAWQA sampled the east-side tributaries and the San Joaquin River site weekly from January 4 to February 23, an additional 24 environmental samples. These samples provided background concentrations at the sites during non-storm periods in January and February.

A dye study was done during the February storm to determine the traveltime from the Merced River at 


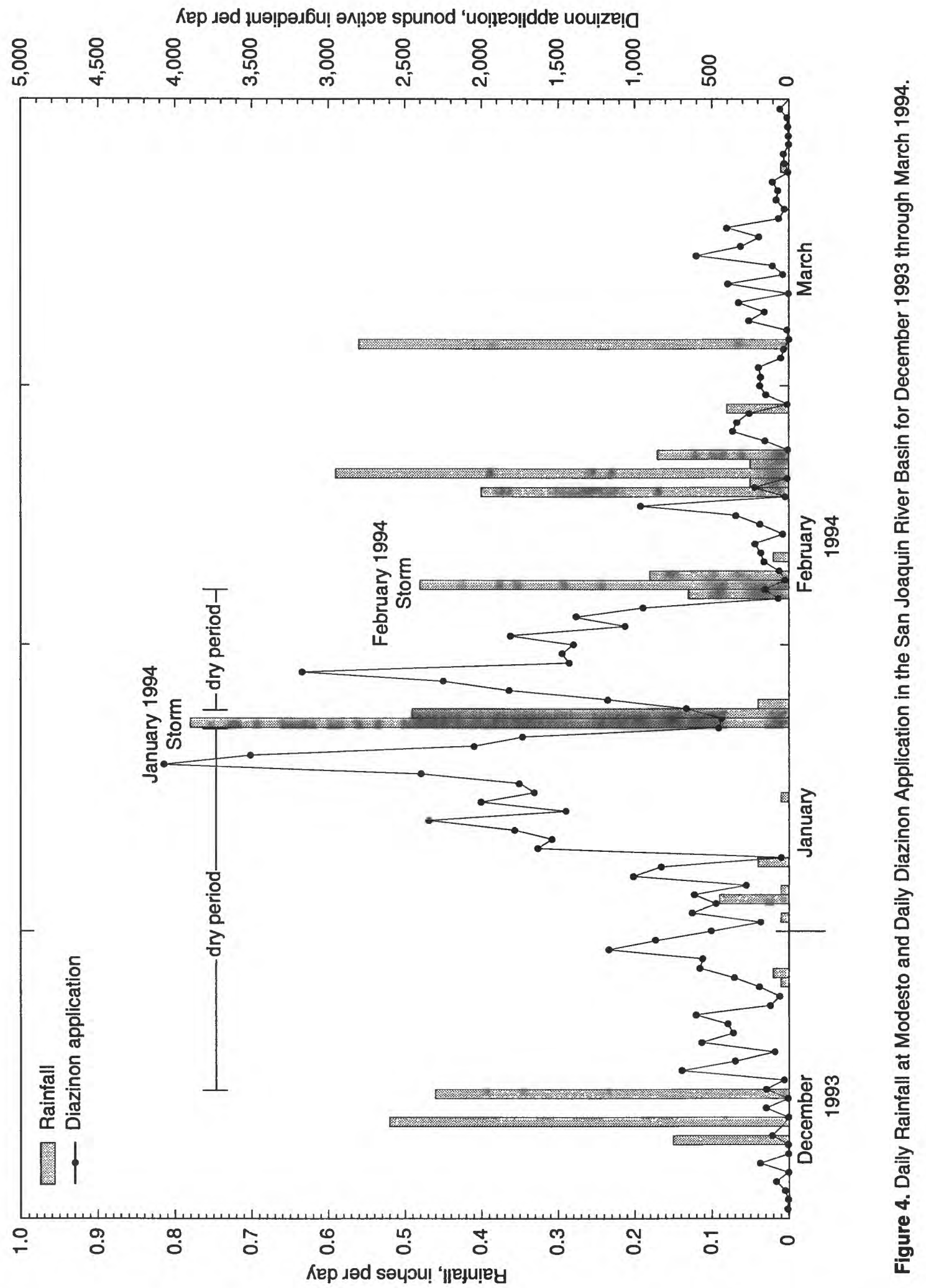



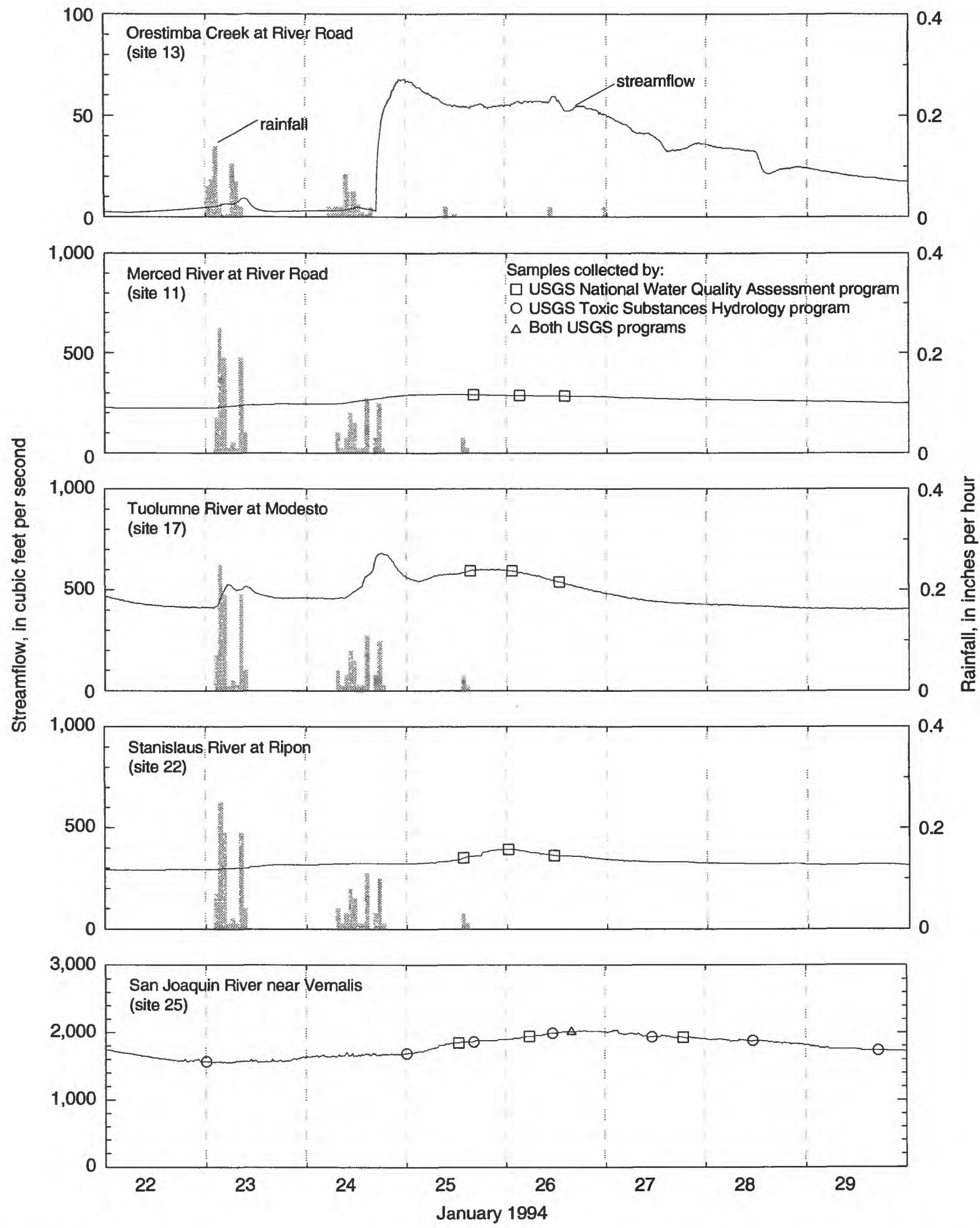

Figure 5. Rainfall, Streamflow, and Sample Collection Times for the January 1994 Storm. [Rainfall shown for Orestimba Creek is average of sites 26 and 28. Rainfall shown for Merced, Tuolumne, and Stanislaus Rivers is site 27. Site numbers refer to Figure 1 and Table 1.] 

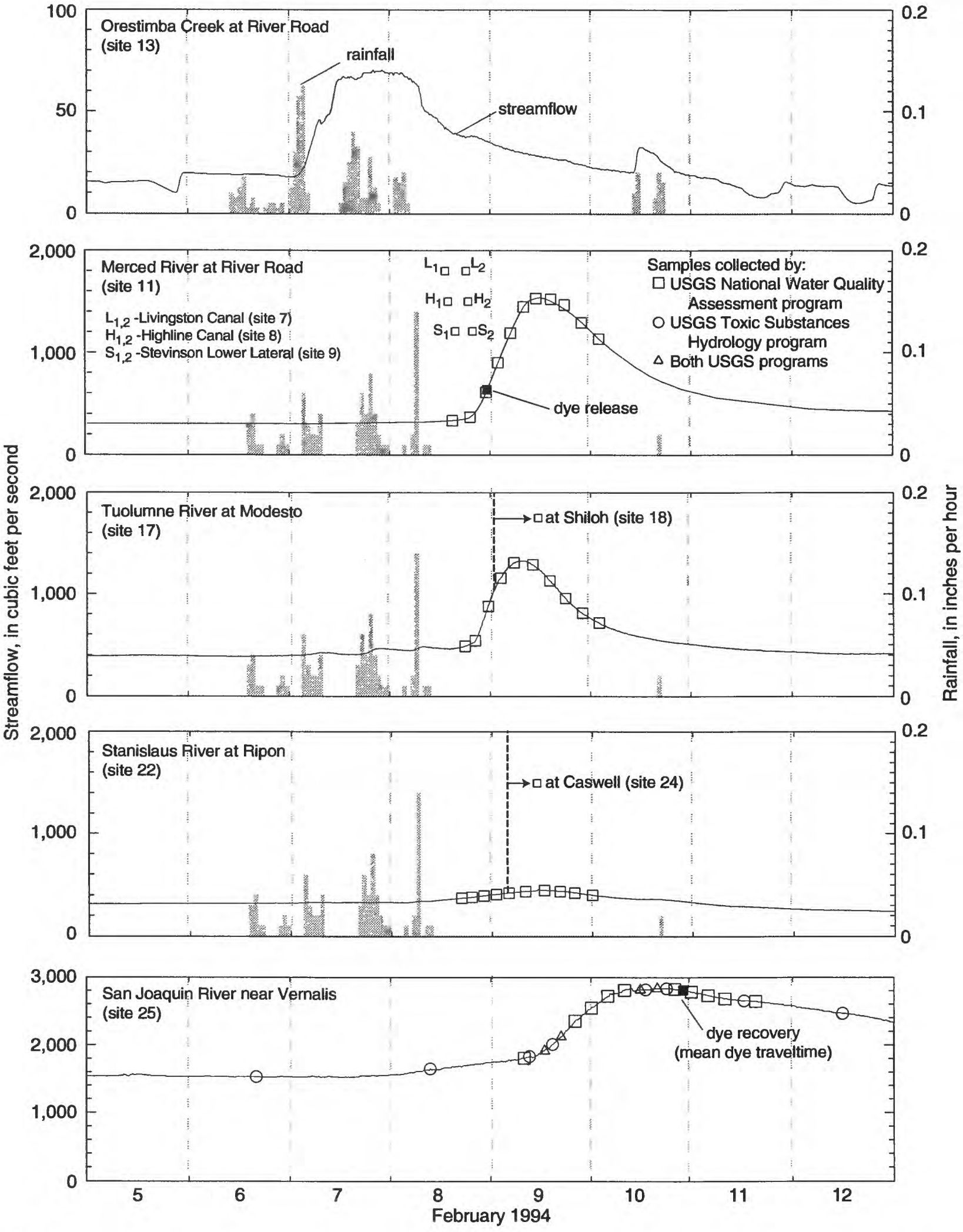

Figure 6. Rainfall, Streamflow, Dye Release and Recovery, and Sample Collection Times for the February 1994 Storm. [Rainfall shown for Orestimba Creek is average of sites 26 and 28. Rainfall shown for Merced, Tuolumne, and Stanislaus Rivers is site 27. Symbols labelled $L_{1}, L_{2}, H_{1}, H_{2}, S_{1}, S_{2}$, at Shiloh, and at Caswell refer to time of sample collections at sites $7,8,9,18$, and 24 . The plotting position does not imply a streamflow. The arrow from the vertical dashed lines to samples collected at sites 18 and 24 refer to the approximate traveltime from upstream samples collected at sites 17 and 22, respectively. Site numbers refer to Figure 1 and Table 1.] 
River Road (site 11) to the San Joaquin River near Vernalis (site 25) (Kratzer and Biagtan, 1997). The traveltime for this 50.5 -mile reach was 38.5 hours. Traveltimes from other sites to Vernalis were estimated from regression equations of mean stream velocity as a function of streamflow (Kratzer and Biagtan, 1997).

\section{Sample Processing and Laboratory Methods}

NAWQA samples were collected as either depthand width-integrated samples using a D-77 isokinetic sampler with Teflon nozzle and 3-liter Teflon bottle (Shelton, 1994) or as grab samples with a 3-liter Teflon bottle strapped into a metal cage suspended from a rope. Samples collected for the Toxics Program were depth-integrated samples collected near the center of flow using a D-74 isokinetic sampler with Teflon nozzle and 1-liter amber glass bottle (Edwards and Glysson, 1988). NAWQA samples were stored on ice and processed (filtered and extracted) within 3 days. The Toxics Program samples were stored in a refrigerator at the Vernalis gage and processed within 1 week.

All of the NAWQA samples and four of the Toxics Program samples were analyzed at the USGS National Water Quality Laboratory (NWQL) in Arvada, Colorado. The rest of the Toxics Program samples were analyzed at the USGS California District Laboratory in Sacramento. All samples were filtered through a baked 0.7-micron glass-fiber filter. For samples analyzed at the NWQL, the dissolved pesticides were extracted by solid-phase extraction (SPE) cartridges containing porous silica coated with a $\mathrm{C}-18$ phase and preconditioned with methanol. The adsorbed pesticides and metabolites were removed from the cartridges by elution with hexane-isopropanol (3:1). Extracts of the eluant were analyzed by a capillarycolumn gas chromatograph/mass spectrometer (GC/MS) operated in the selected-ion monitoring mode (Zaugg et al., 1995). In contrast, the California District Laboratory used SPE cartridges with a C-8 bonded phase, not preconditioned, eluted with hexane:diethyl ether (1:1), and analyzed using a capillary-column GC/MS operated in full-scan mode (Crepeau et al., 1994).

The method detection limit (MDL) is defined as the minimum concentration of a substance that can be identified, measured, and reported with 99-percent confidence that the concentration is greater than zero. The MDL for diazinon at the NWQL was $0.002 \mu \mathrm{g} / \mathrm{L}$, and mean recovery in reagent water spiked with $0.02 \mu \mathrm{g} / \mathrm{L}$ diazinon was 84 percent (Zaugg et al., 1995). The MDL for diazinon at the California District Laboratory was $0.028 \mu \mathrm{g} / \mathrm{L}$, and mean recovery in organic-free water spiked with $0.1 \mu \mathrm{g} / \mathrm{L}$ diazinon was 74 percent (Crepeau et al., 1994). In a linear regression using 25 splits between the NWQL and the California District Laboratory, the NWQL values were higher by 26 percent for the best fit line (with a $\mathrm{R}^{2}$ value of 0.98 ) (Kathryn Kuivila, U.S. Geological Survey, written communication, 1995). Therefore, diazinon samples analyzed at the California District Laboratory were multiplied by 1.26 for use in this paper.

\section{Quality-Control Samples}

Fifteen quality-control (QC) samples were collected by NAWQA out of a total of 105 environmental and QC samples. These QC samples included samples to evaluate the differences between grab and integrated samples (2), replicate samples to evaluate the variability in diazinon concentrations (5), field blanks to evaluate possible contamination (3), and field spikes to evaluate possible degradation between sampling and analysis and the recovery of diazinon in the laboratory (5). The integrated and grab samples agreed within 3 percent and replicates varied by 0 to 14 percent for diazinon. All field blanks were less than detection for diazinon and recoveries in field spikes ranged from 82 to 125 percent.

In addition to the QC samples collected by NAWQA, two samples were collected by the Toxics Program within 30 minutes of NAWQA sample collections and analyzed at the NWQL. The diazinon concentrations in these samples were within 10 percent of the concentrations reported for the NAWQA samples. The Toxics Program also collected seven other samples within 37 minutes of NAWQA samples, which were then analyzed at the California District Laboratory. After multiplying diazinon concentrations by 1.26 , these samples varied by -36 percent to +10 percent relative to the NAWQA samples (median difference of -6 percent; mean difference of -10 percent). 


\section{RESULTS AND DISCUSSION}

\section{Storm Hydrology}

Diazinon transport during winter storms is a function of storm hydrology and diazinon concentrations. Precipitation totals for the 1994 storms are presented in isohyetal maps (Figure 7) on the basis of data from 40 well-distributed precipitation gages. In the January storm, precipitation totals in the Sierra Nevada region of the east-side basins were higher in the Stanislaus River and Tuolumne River Basins. In the February storm, precipitation totals in the Sierra Nevada region of the east-side basins were higher in the Merced River and Tuolumne River Basins (see Figure $2 A$ for basin locations). Precipitation totals in the San Joaquin Valley portion of the east-side basins were higher in the Merced River and Bear Creek Basins, especially during the February storm. Overall, precipitation totals were greater in the San Joaquin Valley during the January storm and in the Sierra Nevada during the February storm. Precipitation totals were similar between storms on the west side. As is typical, precipitation increased from west to east in both storms, except near the crest of the Sierra Nevada (Jo Ann Gronberg, U.S. Geological Survey, written communication, 1995).

The major sources of storm runoff in the Merced River Basin include increased reservoir releases at site 3 (see Figure $1 A$ for site locations), uncontrolled runoff in the Dry Creek subbasin (site 5) and runoff to the Merced River between sites 3 and 11 (Figures $8 A$ and $8 B$ ). Streamflows for site 11 during the January storm are the gaged streamflows at site 10 with the timing adjusted by the appropriate traveltime (Kratzer and Biagtan, 1997). The hydrograph at site 11 for February is estimated because the gage at site 10 was inoperable during the storm. However, three points in the hydrograph at site 10 are known: (1) the time and streamflow before any rise, (2) the time and streamflow early on the rising limb, and (3) the peak of the hydrograph (time unknown). The hydrograph was estimated on the basis of this information and on known streamflows at sites 2, 6, 12, and in Mud and Salt Sloughs (Figure 1). Streamflows for sites 4 and 5 are estimates for both storms because these gages operated by Pacific Gas and Electric are rarely calibrated. Other gages are operated and calibrated either every 2 weeks or monthly by the California Department of Water Resources or by the USGS.

In the Merced River Basin during the January storm (Figure $8 A$ ), there were neither any increased reservoir releases at site 3 nor any storm runoff from the Dry Creek subbasin (site 5). The total storm runoff volume at site 11 was 460 acre-ft. During the February storm (Figure $8 B$ ), increased reservoir releases accounted for about 10 percent of the total storm runoff volume of 3,120 acre-ft at site 11 ; storm runoff from the Dry Creek subbasin contributed over 62 percent.

Storm runoff from Highline and Livingston Canals (sites 7 and 8) accounted for 35 percent of the total storm runoff volume in the Merced River Basin during the January storm (Figure 9A). Highline Canal drains an agricultural basin with a relatively high percentage of almond orchards (Table 2). Livingston Canal drains an area of urban and agricultural land use. The hydrographs for the canals reflect the land use differences between the drainage basins. The January storm followed a long dry period (Figure 4), and agricultural runoff was minimal in the San Joaquin River Basin. Highline Canal was slow to respond relative to the more urbanized Livingston Canal (Figure 9A). During the February storm, there was more agricultural runoff in the San Joaquin River Basin despite less precipitation in the valley compared to the January storm, and Highline Canal responded earlier than Livingston Canal (Figure 9B). The total storm runoff volume in Highline Canal was 140 acre-ft during the January storm and 370 acre-ft during the February storm, compared to Livingston Canal's runoff of 24 and 46 acre-ft during the two storms, respectively.

The major sources of storm runoff in the Tuolumne River Basin include increased reservoir releases at site 14, uncontrolled runoff in the Dry Creek subbasin (site 16), and runoff to the Tuolumne River between sites 14 and 17 (Figure $8 C$ and $8 D$ ). During the January storm, there were no increased reservoir releases, and the Dry Creek subbasin accounted for over 56 percent of the total storm runoff volume of 950 acre-ft at site 17 . The early peaks in the hydrograph on January 23 and 24 at site 17 represent urban runoff from Modesto. During the February storm, increased reservoir releases were small (only 22 acre-ft), and the Dry Creek subbasin accounted for over 76 percent of the total storm runoff volume of 2,100 acre-ft at site 17 . This is typical of winter storms 


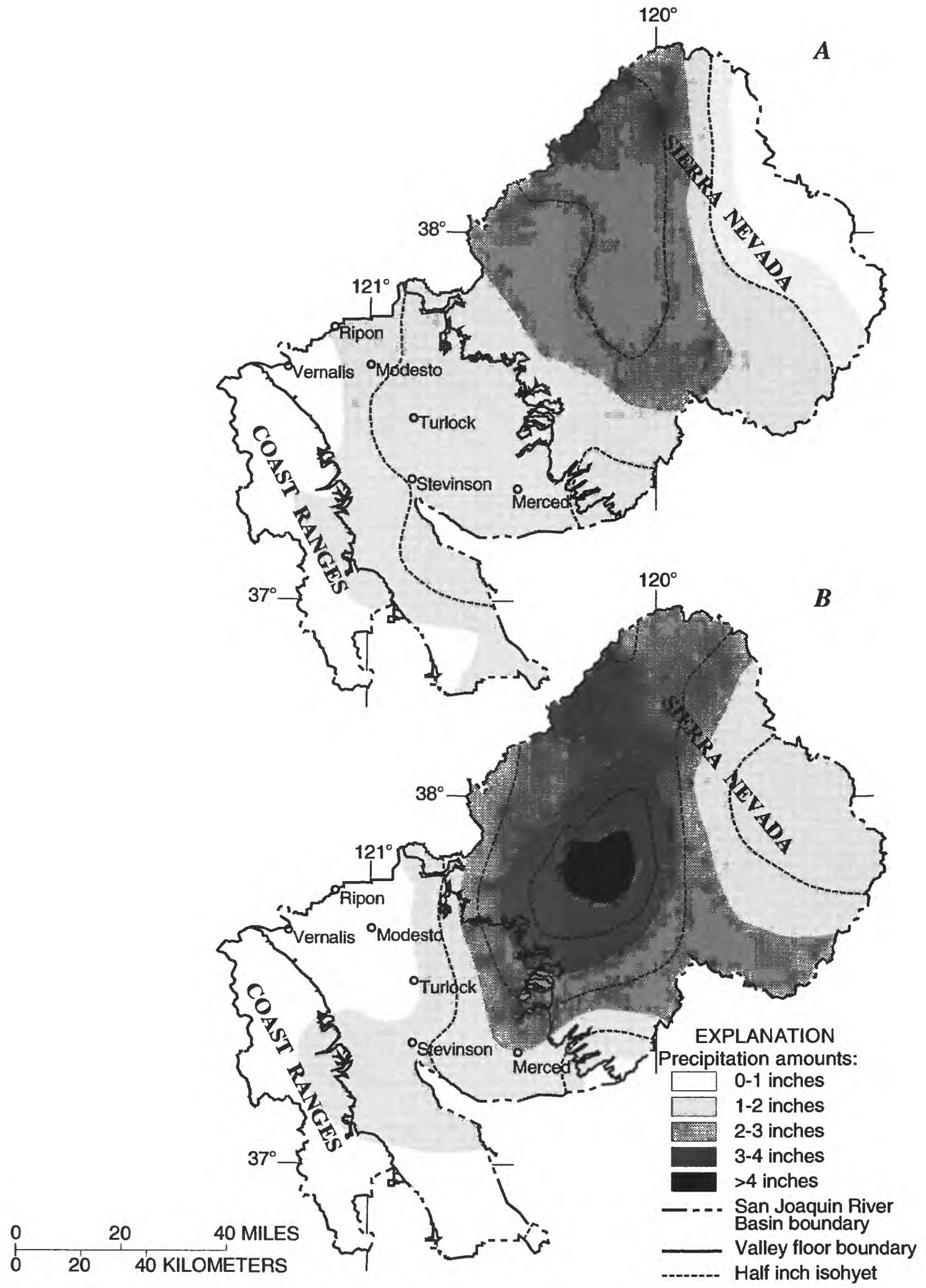

Figure 7. Precipitation Totals for the (A) January 22-26, 1994, and (B) February 5-9, 1994 Storms in the San Joaquin River Basin, California. 

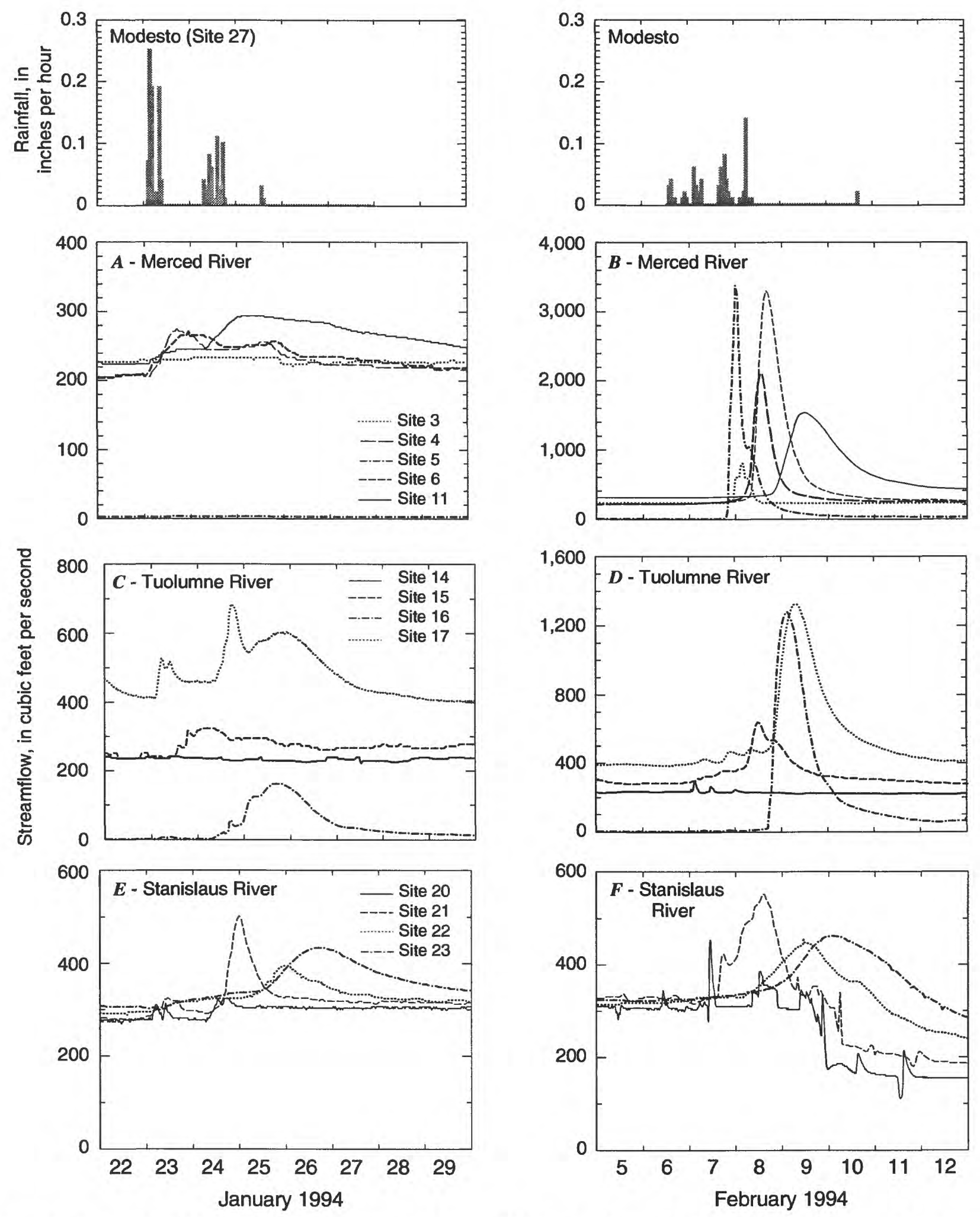

Figure 8. Rainfall and Storm Hydrographs in the Merced $(A, B)$, Tuolumne $(C, D)$, and Stanislaus $(E, F)$ River Basins for January and February 1994. [Site numbers refer to Figure 1 and Table 1.] 

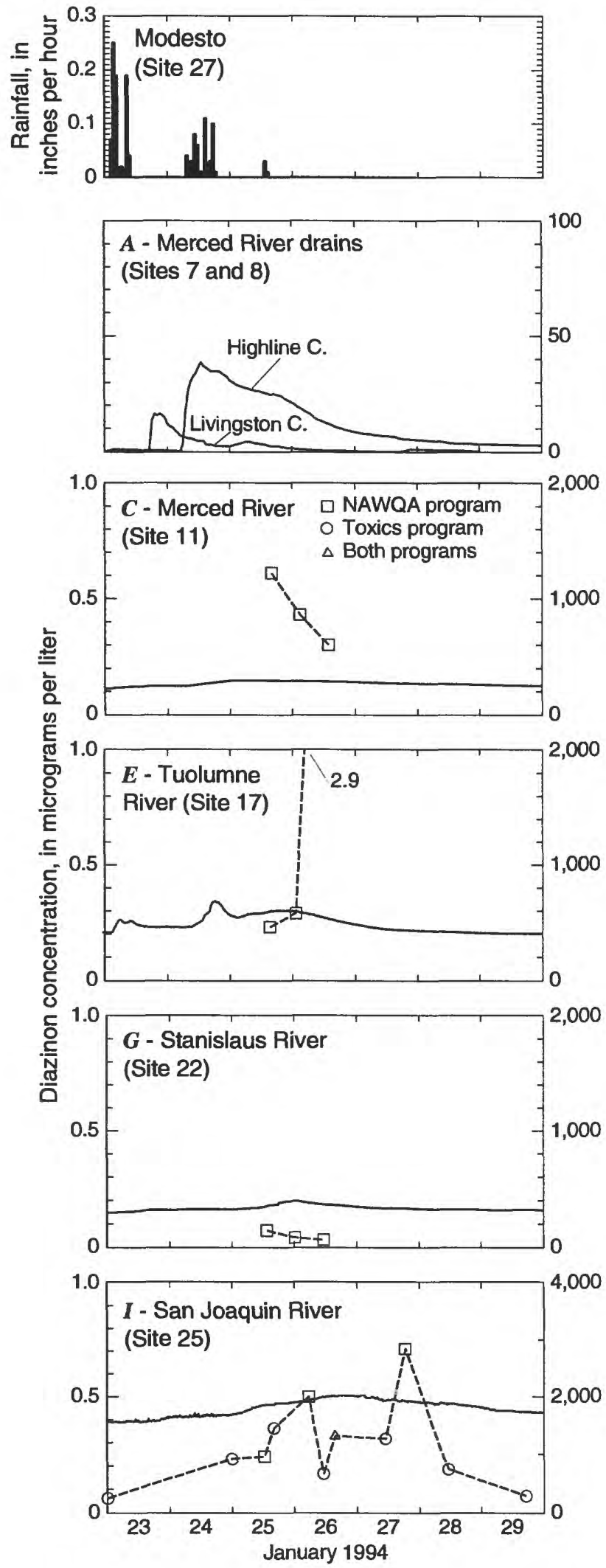
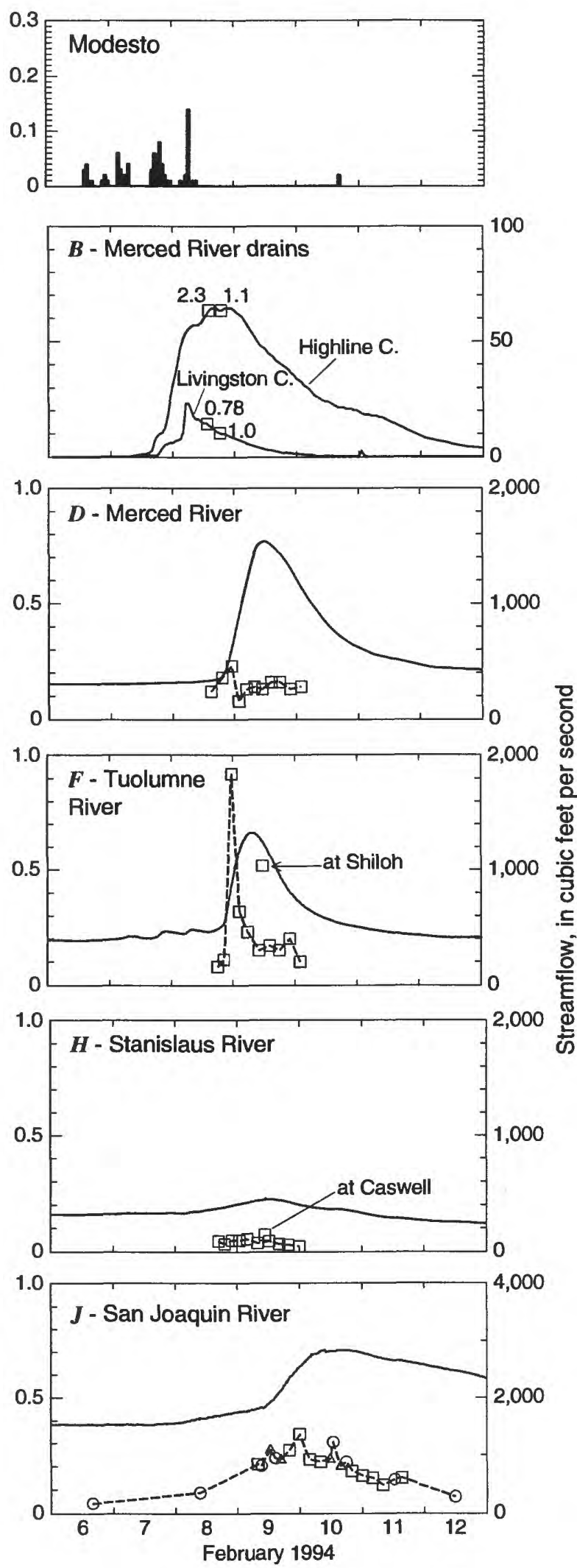

Figure 9. Rainfall and Diazinon Concentrations and Streamflow in East-Side Basins and San Joaquin River during January and February 1994 Storms. [Site numbers refer to Figure 1 and Table 1.] 
in the Tuolumne River Basin, unless reservoir releases are required to maintain adequate flood control space. Nevertheless, storm runoff in the valley is primarily through the Dry Creek subbasin. The urban runoff from Modesto during February appears as small peaks on February 7 and 8.

The major sources of storm runoff in the Stanislaus River Basin include increased reservoir releases at site 20 and runoff between sites 20 and 23 (Figure $8 E$ and $8 F$ ). During the January storm, increased reservoir releases accounted for 150 acre-ft of the total storm runoff volume of 530 acre- $\mathrm{ft}$ at site 23 (Figure $8 E$ ). Because New Melones Reservoir rarely makes releases for flood control, the increased reservoir releases at site 20 during winter storms generally are due to uncontrolled inflows from Black Creek (site 19) and other small streams. However, during the January storm, Black Creek runoff totalled only 20 acre-ft. During the February storm, increased reservoir releases (net) accounted for 84 acre-ft of the total storm runoff volume at site 23 of 440 acre-ft. Black Creek runoff totalled about 55 acre-ft. Reservoir releases were reduced on February 9, resulting in long falling limbs to the hydrographs at sites 21,22 , and 23 (Figure $8 F$ ).

The total storm runoff volume in the San Joaquin River Basin during the January storm (Figure 5) was 3,100 acre-ft. The Merced River Basin accounted for 15 percent of this volume; the Tuolumne 30 percent; and the Stanislaus 17 percent. The remaining 38 percent was from ephemeral west-side creeks (basin M), east-side drainage directly to the San Joaquin River (basin L), Mud and Salt Sloughs (basin N), and Bear Creek (basin A). Total storm runoff volume during the February storm (Figure 6) was 8,100 acre-ft. The Merced River Basin accounted for 39 percent; the Tuolumne for 26 percent; and the Stanislaus for 5 percent. Runoff in Orestimba Creek (site 13), the largest ephemeral west-side creek, accounted for 10 percent of the January storm total, and about 2 percent of the February total. The total storm runoff volume in the east-side basins during the January storm generally reflected the differences in valley drainage basin sizes (Table 2). Total storm runoff volumes during the February storm reflected the greater precipitation in the Merced River and Tuolumne River Basins (Figure 7), as well as the differences in valley drainage basin sizes (Figure $2 A$ ).

\section{Diazinon Concentration}

Diazinon concentrations were highly variable during the hydrographs for the 1994 storms, especially in the Tuolumne and Merced Rivers (Figure 9). On the basis of storm sampling in 1993 (Domagalski et al., 1997), this was also likely true for Orestimba Creek at River Road (site 13) during the 1994 storms. The January 1994 storm produced higher peak diazinon concentrations than the February 1994 storm in the Merced, Tuolumne, and San Joaquin Rivers, but the February storm produced more storm runoff. Diazinon concentrations and storm runoff were relatively low in the Stanislaus River during both storms.

Diazinon concentrations in the Merced River were higher during the January storm than during the February storm, despite sampling only the falling limb of the hydrograph. Pesticide concentrations are usually higher on the rising limb than on the falling limb of storm hydrographs (Figures $9 D$ and $9 F$ ) (Richards and Baker, 1993). The Merced River drains were sampled in February near the peak streamflow for Highline Canal and on the falling limb for Livingston Canal (Figure 9B). Based on estimated traveltimes (Kratzer and Biagtan, 1997), these samples correspond to samples after the concentration peak at site 11. If these drains had similar diazinon concentrations on the rising limbs, they would account for most of the diazinon in the Merced River. If these drains had similar concentrations in the January storm, they would account for most of the diazinon then as well. The third Merced River drain (site 9) was a small source of diazinon (not shown in Figure 9) in the February storm, with concentrations of 0.16 and $0.13 \mu \mathrm{g} / \mathrm{L}$ at a streamflow of only about $3 \mathrm{ft}^{3} / \mathrm{s}$.

The Tuolumne River had the highest diazinon concentrations in both storms. Most urban storm drains in Modesto stop flowing within 4 hours following significant rainfall (City of Modesto, 1993). On the basis of estimated traveltimes (Kratzer and Biagtan, 1997), the samples of the Tuolumne River (site 17) in the January and February storms were taken after most urban runoff had ceased. On the basis of the storm hydrographs at site 16 (Figure 8) and estimated traveltimes, all samples in the January storm were of agricultural runoff and the first two samples in February were after the urban runoff, but before significant agricultural runoff. The peak concentration of $2.9 \mu \mathrm{g} / \mathrm{L}$ in the 
Tuolumne River in January was unexpected, because it occurred on the falling limb of the hydrograph. The value was confirmed by two QC samples: an integrated split with a concentration of $2.7 \mu \mathrm{g} / \mathrm{L}$, and a grab sample with a concentration of $2.8 \mu \mathrm{g} / \mathrm{L}$. The downstream sample taken in February at the Tuolumne River at Shiloh Road (site 18) corresponded to a period of rapid change in diazinon concentrations between the third and fourth samples at site 17 (Figure 9). Because the traveltime regression equation (Kratzer and Biagtan, 1997) for the Tuolumne River is not very reliable, the Shiloh Road sample does not provide much information on possible diazinon inputs downstream of Modesto.

The Stanislaus River had low diazinon concentrations in both storms, consistent with previous sampling efforts (Ross et al., 1996). On the basis of estimated traveltimes, the sample taken at the downstream site, Stanislaus River at Caswell State Park (site 24), corresponded to the peak concentration at site 22 of $0.054 \mu \mathrm{g} / \mathrm{L}$. The increased concentration in the downstream sample to $0.072 \mu \mathrm{g} / \mathrm{L}$ was probably caused by an input of diazinon between sites 22 and 24 . However, the concentration and streamflow was still relatively low.

Diazinon concentrations in the San Joaquin River near Vernalis reflect the variability of diazinon concentrations in the different sources of storm runoff and their respective traveltimes (Kratzer and Biagtan, 1997). The peak concentration in both storms corresponded to the peak concentrations in the Tuolumne River on the basis of approximate traveltime. A total of 41 samples ( 35 from the Toxics Program and 6 from the NAWQA Program) were collected at the San Joaquin River near Vernalis in January and February 1994 outside of the storm periods shown in Figure 9. The median diazinon concentrations for these samples was $0.044 \mu \mathrm{g} / \mathrm{L}$, with a maximum of $0.136 \mu \mathrm{g} / \mathrm{L}$. For the 41 samples, the 8 samples collected between storms (i.e., between January 30 and February 5) had a median concentration of $0.098 \mu \mathrm{g} / \mathrm{L}$ and included the five highest concentrations of the non-storm samples. Six NAWQA samples also were collected from each of the three east-side tributaries outside of the storm periods. The median diazinon concentrations for these samples were $0.020 \mu \mathrm{g} / \mathrm{L}$ for the Merced River, $0.011 \mu \mathrm{g} / \mathrm{L}$ for the Tuolumne River, and $0.006 \mu \mathrm{g} / \mathrm{L}$ for the Stanislaus River. Thus, diazinon concentrations in the San Joaquin River Basin were much lower during non-storm periods in January and February of 1994 as compared to the two storm periods.

\section{Diazinon Transport}

The transport of diazinon in pounds active ingredient (lb a.i.) per day to the San Joaquin River near Vernalis (site 25) during the January and February storms is presented in Figure 10. Diazinon loads from east-side tributaries are presented in "Vernalis time" by adding the estimated traveltime from the sampling site to the San Joaquin River near Vernalis (Kratzer and Biagtan, 1997). The periods when loads from unsampled sources were calculated to be at Vernalis are shown in the horizontal bars across the top of Figure 10 for west-side sources (basin M, Figure 2), other eastside sources (basin L), and the Bear Creek Basin (basin A). These periods are based on the duration of the storm hydrographs in the basins and the estimated traveltimes from each basin to Vernalis. Mud and Salt Sloughs drainage basin (basin N), which is not shown in the figure, is assumed to be a very minor source of diazinon, on the basis of limited USGS sampling and the relatively small amounts of diazinon applied (Table 2).

In the January storm, the peak load of diazinon in the San Joaquin River near Vernalis is attributed to the load from the Tuolumne River (Figure 10). The diazinon load at Vernalis on January 25 is attributed to west-side sources. Most of the load on January 26 reflects contributions from both west-side sources and other east-side sources, including urban runoff from Modesto and the load from the rising limb of the Merced River hydrograph (prior to sampling; Figure 9 C). Most of the load on January 27 probably can be attributed to the Tuolumne and Merced Rivers. Most of the load on January 28 probably can be attributed to the falling limb of the Tuolumne River hydrograph (after sampling; Figure $9 E$ ).

In the February storm, there are two peaks in loads in the San Joaquin River near Vernalis (Figure 10). The diazinon loads on February 7 and 8 are attributed to west-side sources. Most of the load on February 9, prior to the large Tuolumne River input, is attributed to west-side sources and other east-side sources, including urban runoff from Modesto. The Tuolumne River is the major source of the first peak. 


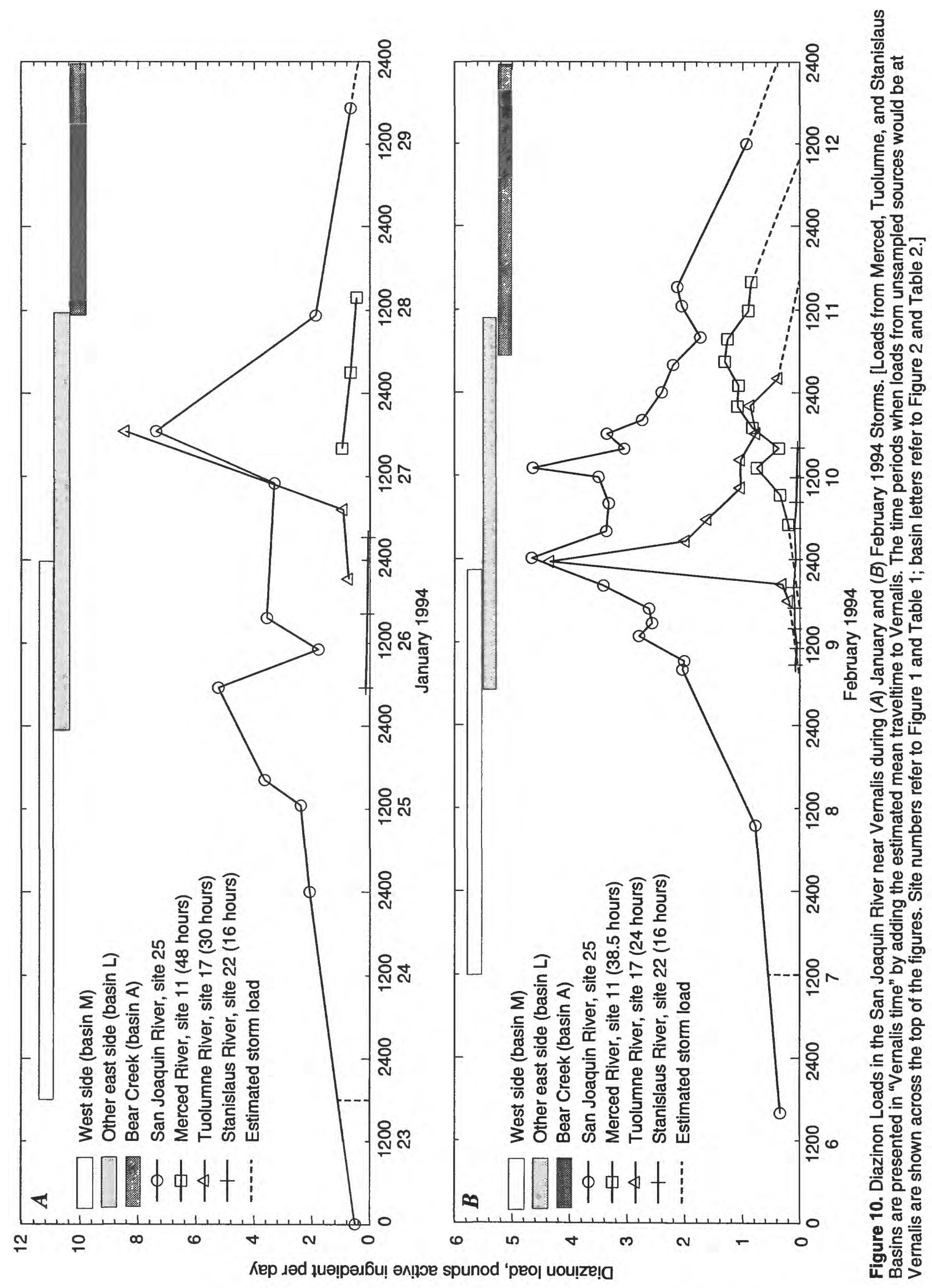


The loads on February 10, including the second peak, are attributed to the Tuolumne and Merced Rivers plus other east-side sources. The Merced River is the main source on February 11, with increasing inputs from Bear Creek Basin later on February 11 and 12.

In both storms, the diazinon loads were highly variable and required frequent sampling to attain good estimates. The diazinon loads during storm runoff in the San Joaquin River are completed with dashed lines in Figure $10 \mathrm{~A}$ and $10 \mathrm{~B}$ to estimate total load transport for each storm. For the east-side tributaries, total loads are estimated only for the February storm because of the shortage of samples for the January storm. Nonstorm, "background" loads were calculated from nonstorm concentrations and streamflows in January and February 1994. These background loads were $2.66 \mathrm{lb}$ a.i. for the San Joaquin River during the January storm, $2.27 \mathrm{lb}$ a.i. for the San Joaquin River during the February storm, $0.07 \mathrm{lb}$ a.i. for the Merced River, $0.08 \mathrm{lb}$ a.i. for the Tuolumne River, and $0.02 \mathrm{lb}$ a.i. for the Stanislaus River. These background loads were subtracted from the total loads shown in Figure 10 to estimate total storm loads. The total diazinon storm load in the San Joaquin River near Vernalis, during the January storm, was $19.6 \mathrm{lb}$ a.i., compared to $7.8 \mathrm{lb}$ a.i. during the February storm. Thus, more than twice the diazinon was transported during the January storm, with only 38 percent as much total storm runoff volume $(3,100$ acre-ft versus 8,100 acre- $\mathrm{ft}$ ) as in the February storm. However, this transport, as a percent of the application (Table 2) during the preceding dry period, was about 0.05 percent for both storms.

The Tuolumne River appears to have been the major east-side tributary source of diazinon during the January storm, on the basis of limited sampling. For the February storm, the Tuolumne River accounted for $1.8 \mathrm{lb}$ a.i. of the $7.8 \mathrm{lb}$ a.i. total in the San Joaquin River near Vernalis. The Merced River accounted for $1.5 \mathrm{lb}$ a.i. and the Stanislaus River only $0.1 \mathrm{lb}$ a.i. Thus, most of the diazinon load $-4.4 \mathrm{lb}$ a.i. (56 percent) — came from other, unsampled sources. This corresponds with the application of diazinon: 79 percent of the total application during the first dry period and 61 percent during the second dry period was in unsampled basins.

The January and February storms are presented in the context of daily diazinon concentrations and loads in the San Joaquin River near Vernalis in
Figure 11. Total diazinon transport during the calendar years 1991-1993 was 30, 88, and $339 \mathrm{lb}$ a.i., respectively. The main factor for diazinon transport seems to be the occurrence of sizable storms in January and February. For 1991-1993, 74 percent of the total diazinon transport from the San Joaquin River Basin occurred in January and February. The only toxic concentrations of diazinon (greater than $0.35 \mu \mathrm{g} / \mathrm{L}$ ) also occurred in January and February.

\section{SUMMARY AND CONCLUSIONS}

Most diazinon application in the San Joaquin River Basin occurs on dormant almond orchards. Transport to the San Joaquin River occurs primarily during January and February storms. The major east-side tributaries, individual drains in the Merced River Basin, and the downstream site on the San Joaquin River were sampled throughout two storms in 1994. The main sources of storm runoff in the Merced River Basin were uncontrolled inflow from Dry Creek and two gaged drain inflows. The main sources of storm runoff in the Tuolumne River Basin were uncontrolled inflow from another Dry Creek and urban runoff from Modesto. The Stanislaus River Basin had very little runoff during both storms.

Diazinon concentrations and loads were highly variable and required frequent sampling to describe the concentration curves and to estimate loads. The highest concentrations during both storms occurred in the Tuolumne River. Two drains in the Merced River Basin, one agricultural and the other a combination of agricultural and urban, probably accounted for most of the diazinon in the Merced River runoff. Diazinon concentrations in the Stanislaus River Basin were low during both storms.

The Tuolumne River was the largest east-side tributary source of diazinon load during both storms, followed by the Merced River. The Stanislaus River was a small source during both storms. In the February storm, most of the diazinon load came from other, unsampled sources. This corresponds with diazinon application: 79 percent of the total application during the first dry period and 61 percent during the second dry period was in unsampled basins. On the basis of previous storm sampling and estimated traveltimes, ephemeral west-side creeks were probably the main diazinon source early in the storms, while the Tuolumne and Merced Rivers, and east-side drainage 

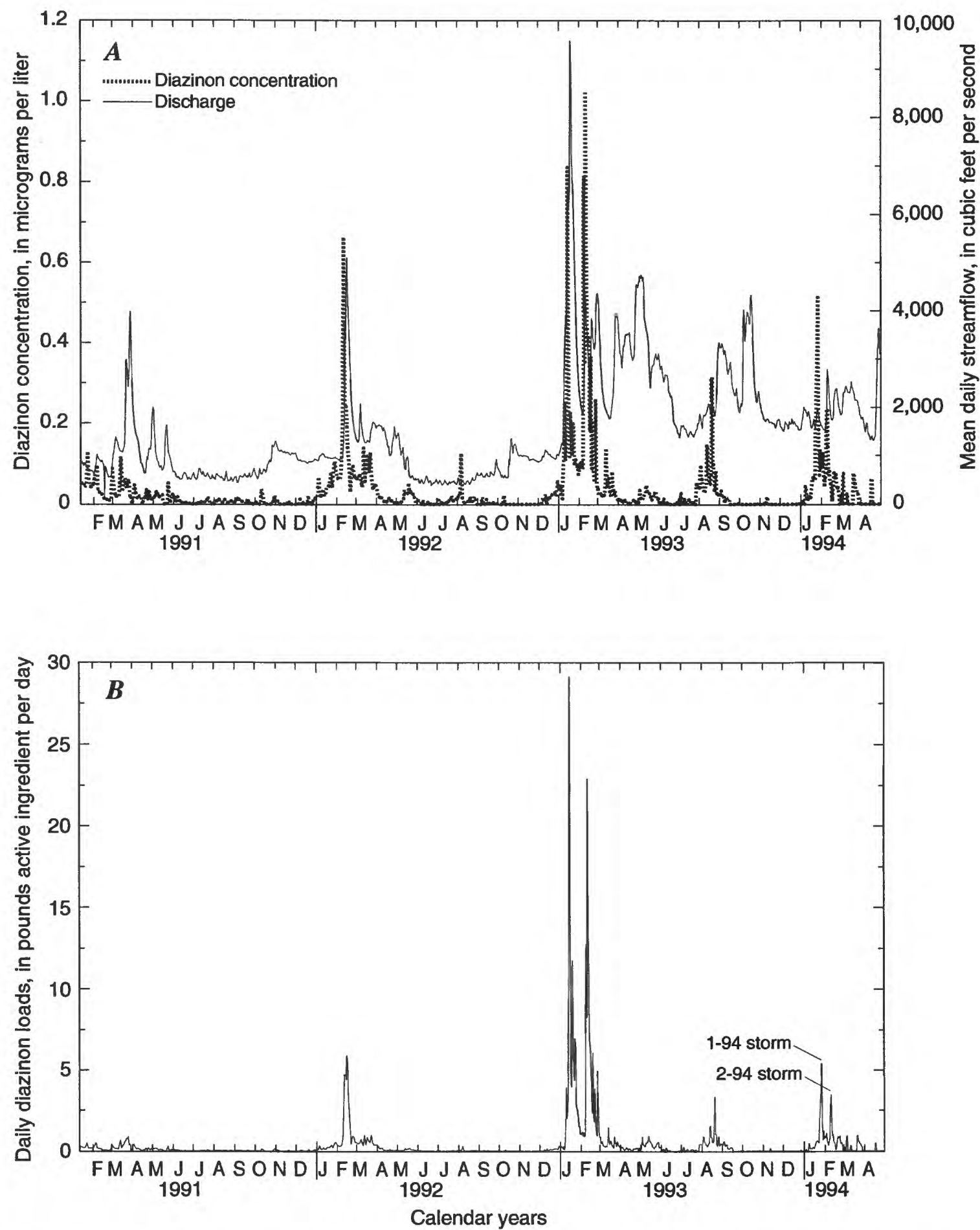

Figure 11. ( $A$ ) Daily Mean Diazinon Concentrations and Streamflow; and $(B)$ Daily Diazinon Loads in the San Joaquin River near Vernalis during February 1991 through April 1994.

directly to the San Joaquin River, were the main sources later. Despite only 38 percent as much total storm runoff volume, the January storm transported more than twice as much diazinon as did the February storm. For 1991-1993, 74 percent of the total diazinon transport from the San Joaquin River Basin 
occurred in January and February. The diazinon load transported in each 1994 storm was 0.05 percent of the total applied during the preceding dry period.

\section{LITERATURE CITED}

Amato, J.R., D.I. Mount, E.J. Durhan, M.T. Lukasewycz, G.T. Ankley, and E.D. Robert, 1992. An Example of the Identification of Diazinon as a Primary Toxicant in an Effluent. Environmental Toxicology and Chemistry 11(2):209-216.

California Department of Pesticide Regulation, [1994]. Pesticide Use Data for 1993. California Department of Pesticide Regulation, Sacramento, California. [Digital data].

California Department of Pesticide Regulation, [1995]. Pesticide Use Data for 1994. California Department of Pesticide Regulation, Sacramento, California. [Digital data].

City of Modesto, 1993. Application for NPDES (National Pollutant Discharge Elimination System) Municipal Stormwater Permit, Part 2. Public Works and Transportation Department, Modesto, California.

Crepeau, K.L., J.L. Domagalski, and K.M. Kuivila, 1994. Methods of Analysis and Quality-Assurance Practices of the U.S. Geological Survey Organic Laboratory, Sacramento, California-Determination of Pesticides in Water by Solid-Phase Extraction and CapillaryColumn Gas Chromatography/Mass Spectrometry. U.S. Geological Survey Open-File Report 94-362, 17 p.

Domagalski, J.L., N.M. Dubrovsky, and C.R. Kratzer, 1997. Pesticides in the San Joaquin River, California: Inputs from Dormant Sprayed Orchards. Journal of Environmental Quality 26(2):454-465.

Edwards, T.K., and G.D. Glysson, 1988. Field Methods for Measurement of Fluvial Sediment. U.S. Geological Survey Open-File Report 86-531, 118 p.

Foe, C.G., and K.M. Kuivila, 1995. Diazinon Pulses in the Sacramento and San Joaquin Rivers. Water Quality
News, California Department of Water Resources, Winter 1995, pp. 10-15.

Howard, P.H., 1991. Handbook of Environmental Fate and Exposure Data for Organic Chemicals. Volume III: Pesticides. Lewis Publishers, Ann Arbor, Michigan, $684 \mathrm{p}$.

Kratzer, C.R., and R.N. Biagtan, 1997. Determination of Traveltimes in the Lower San Joaquin River Basin, California, from Dye-Tracer Studies during 1994-1995. U.S. Geological Survey Water-Resources Investigations Report 97-4018, 20 p.

Kuivila, K.M., and C.G. Foe, 1995. Concentrations, Transport and Biological Effects of Dormant Spray Pesticides in the San Francisco Estuary, California. Environmental Toxicology and Chemistry 14(7):1141-1150.

MacCoy, D., K.L. Crepeau, and K.M. Kuivila, 1995. Dissolved Pesticide Data for the San Joaquin River at Vernalis and the Sacramento River at Sacramento, California, 1991-94. U.S. Geological Survey Open-File Report 95-110, 27 p.

Richards, P.R., and D.B. Baker, 1993. Pesticide Concentration Patterns in Agricultural Drainage Networks in the Lake Erie Basin. Environmental Toxicology and Chemistry 12(1):13-26.

Ross, L.J., R. Stein, J. Hsu, J. White, and K. Hefner, 1996. Distribution and Mass Loading of Insecticides in the San Joaquin River, California, Winter 1991-92 and 1992-93. California Department of Pesticide Regulation Report No. EH 96-06, variously paged.

Shelton, L.R., 1994. Field Guide for Collecting and Processing Stream-Water Samples for the National Water-Quality Assessment Program. U.S. Geological Survey Open-File Report 94-455, 42 p.

Zaugg, S.D., M.K. Sandstrom, S.G. Smith, and K.M. Fehlberg, 1995. Methods of Analysis by the U.S. Geological Survey National Water Quality Laboratory-Determination of Pesticides in Water by C-18 Solid-Phase Extraction and Capillary-Column Gas Chromatography/Mass Spectrometry with Selected-Ion Monitoring. U.S. Geological Survey Open-File Report 95-181, 49 p. 